\title{
UK was advised to stockpile PPE and screen travellers in 2016 after coronavirus modelling
}

\section{Gareth lacobucci}

The government was warned four years before the covid-19 pandemic of the need to stockpile personal protective equipment, screen international travellers, and set up a contact tracing system in the event of a major outbreak of a coronavirus, a previously unpublished report has revealed. ${ }^{1}$

The report, which summarises key action points for a future pandemic after a simulation exercise, called exercise Alice, of a "large scale outbreak" of Middle East respiratory syndrome in February 2016, was commissioned by England's former chief medical officer, Sally Davies, who attended with officials from the Department of Health for England, Public Health England, and NHS England.

The report was obtained under Freedom of Information Act and published online by Moosa Qureshi, an NHS consultant haematologist who has been campaigning for greater transparency in the government's preparedness for the pandemic. ${ }^{23}$ The government had initially refused to release the report on the grounds that it could "lead to loss of public confidence in the government's and the NHS' covid-19 response" but eventually released it.

Although distinct from SARS-CoV-2, MERS shares characteristics as both can cause severe respiratory disease and spread asymptomatically.

The report noted that, during the simulation, the "level and use of PPE was central to the exercise dialogue and considered of crucial importance for frontline staff" and that "pandemic stockpiles were suggested as a means to ensure sufficient quantities were available.”

Suggested measures included "port of entry screening" to restrict the spread of a virus from abroad and for officials to draw up an "options plan using extant evidence and cost benefits for quarantine versus self-isolation for a range of contact types, including symptomatic, asymptomatic, and high risk groups."

Officials also recommended developing a plan for the process of community sampling and emphasised the need to develop a tool or system to trace contacts of people who had been infected by the virus, suggesting a "live database of contacts with classifications, current state, and other data germane to the situation."

Several of these action points later emerged as weaknesses in the UK's response to covid-19 in 2020, with the government criticised for shortages of PPE in care homes and hospitals, continuing to allow people to enter the UK without being screened (including from countries with high covid rates), and failing to launch a test and trace service until May
2020, more than two months after the peak of the first wave of the pandemic.

Qureshi said, “Disgracefully, the government covered up exercise Alice-a coronavirus exercise which predicted the importance of isolating patients, contact tracing, PPE provision, trained personnel, and adequate NHS beds.

"The fact that [SARS-CoV-2] is a novel type of coronavirus is irrelevant: every pandemic is different. But the lessons of exercise Alice were generally applicable to coronaviruses, including covid-19, they were agreed by general consensus, and both political leaders and NHS England executives failed to implement that consensus."

The report concluded, "There was a general consensus on the need to identify capacity and capability of assets within the health system. Assets in this context would be all resources that would be required to effectively respond to a MERS-CoV outbreak such as trained personnel, appropriate PPE in sufficient quantities, and the requisite beds with suitable clinical equipment."

Tessa Gregory, a partner at the law firm Leigh Day, which has represented Qureshi, urged the government to "disclose all the information they have in their possession including what follow-up action was taken after exercise Alice in 2016 and why matters such as a proper working contact tracing system had not already been set up. The public have a right to know about the steps the government took and didn't take to prepare for pandemics, and full disclosure is essential in order to manage covid-19 and future pandemics effectively.”

A government spokesperson said that MERS-CoV was different from SARS-CoV-2 and that exercise Alice was not a coronavirus pandemic preparedness exercise.

"MERS-CoV does not transmit as easily as SARS-CoV-2 between people, outbreak sizes are comparatively small, and the risk to individuals in the UK remains very low," the spokesperson said. "The results of exercise Alice have been incorporated into ongoing planning work conducted by DHSC, UKHSA, and the NHS to respond to potential outbreaks of high consequence infectious diseases like MERS-CoV.

"We have always been clear that there will be opportunities to look back, analyse, and reflect on all aspects of covid-19, and a full statutory independent inquiry is due to begin in spring 2022."

Public Health England. Report: Exercise Alice Middle East respiratory syndrome (MERS-CoV). 2016. https://cygnusreports.org/wp-content/uploads/2021/10/Report-Exercise-Alice-Middle-East-Respiratory-Syndrome15-Feb-2016.pdf. 
2 Dyer C. Pandemic preparedness: doctor leads campaign for UK government to release report. BMJ 2020;369:m1732. doi: 10.1136/bmj.m1732 pmid: 32349981

3 Dyer C. Pandemic preparedness: UK government kept coronavirus modelling secret. BMJ 2021;373:n1501. doi: 10.1136/bmj.n1501 pmid: 34117008

This article is made freely available for use in accordance with BMI's website terms and conditions for the duration of the covid-19 pandemic or until otherwise determined by BMJ. You may use, download and print the article for any lawful, non-commercial purpose (including text and data mining) provided that all copyright notices and trade marks are retained. 